\title{
面向湖泊生态系统健康维护的生态管控分区研究
} 以红枫湖流域为例

\author{
蒋 啸, 周 旭 ${ }^{*}$, 肖 杨, 罗雪, 杨大方 \\ 贵州师范大学地理与环境科学学院, 贵阳 550025
}

\begin{abstract}
摘要: 以湖泊生态系统健康维护为目标的生态管控分区成为水环境保护与治理的重要手段,有助于全面掌握流域生态状况,对 流域生态经济可持续发展具有重要参考价值。以红枫湖流域为例, 从水文水资源、物理结构、水质、生物、社会服务功能 5 个方 面对湖泊生态系统健康进行评价。运用 ArcGIS 空间分析工具, 以 $200 \mathrm{~m} \times 200 \mathrm{~m}$ 格网为评价单元辨析流域生态敏感性和生态服 务功能空间分异特征,进而运用 SOFM 聚类方法优选聚类方案,划定生态管控分区。结果表明:1) 红枫湖湖泊生态系统健康评 分为 68.4 分, 属健康状态,物理结构是当前威胁红枫湖湖泊生态系统健康的主要因子;2) 红枫湖流域生态敏感性及生态服务功 能空间差异明显,生态环境脆弱,生态服务功能较低;3)红枫湖流域生态管控分区划为优先控制区、重点控制区、缓冲控制区及 一般控制区,应实施差异化管理,重点任务是调结构、转方式,逐步修复生态系统。
\end{abstract}

关键词: 湖泊生态系统;生态敏感性;生态服务功能;生态管控分区

\section{Ecological space zoning based on lake ecosystem health maintenance: taking the Hongfeng Lake basin as example}

\author{
JIANG Xiao,ZHOU Xu ${ }^{*}$, XIAO Yang, LUO Xue, YANG Dafang \\ School of Geography and Environmental Science, Guizhou Normal University, Guiyang 550025, China
}

\begin{abstract}
Ecological management and control zoning aiming at the health maintenance of lake ecosystem has become an important means of water environmental protection and management. It is helpful to comprehensively grasp the ecological status of the basin and has important reference value for the sustainable development of the ecological economy in the basin. Taking Hongfeng Lake basin as an example, the lake ecosystem health was evaluted from five aspects: hydrological and water resources, physical structure, water quality, biology and social services. Using ArcGIS spatial analysis tools, taking $200 \mathrm{~m} \times 200 \mathrm{~m}$ grid as evaluation unit, this paper analyzes the spatial differentiation characteristics of watershed ecological sensitivity and ecological service function, and then uses Self-Organizing Feature Maps clustering method to optimize the optimal clustering scheme and divide the ecological divisions. The results show that: 1) Hongfeng Lake ecosystem health score is 68.4 , which is in a healthy state. The physical structure is a key factor threatening the ecosystem health of Hongfeng Lake. 2 ) The ecological sensitivity and spatial distribution of ecological service function of Hongfeng Lake Basin are obviously different, the ecological environment is fragile, and the service function of the ecosystem is low. 3 ) The Hongfeng watershed is divided into priority control area, key control area, buffer control area and general control area to implement differentiated management measures. The key task is to adjust the structure, change the mode, and gradually restore the

基金项目:国家自然科学基金委员会-贵州省人民政府喀斯特科学研究中心项目(U1812401); 贵州省科技支撑项目（黔科合支撑 [2017] 2855); 贵州省科学技术项目(黔科合基础 [2017]1131); 贵州师范大学研究生创新基金项目(YC[2018]045)

收稿日期: 2019-07-30; 网络出版日期:2021-01-28

* 通讯作者 Corresponding author.E-mail: zxzy8178@163.com
\end{abstract}


ecosystem.

Key Words: Lake ecosystem; ecological sensitivity; ecological service function; ecological control zoning

在全球水生态危机频发的背景下,湖泊生态系统健康理论作为衔接湖泊科学、生态学、水文学的关键纽 带, 为湖泊流域管理提供科学依据 ${ }^{[1-4]}$ 。20 世纪 80 年代, Schaeffer 和 Rapport 认为健康的生态系统具有维持 其组织结构、自我调节和对胁迫的恢复能力,可为人类提供良好的生态系统服务功能 ${ }^{[5-6]}$ 。迄今, 国内外湖泊 生态系统健康方面的研究成果丰硕, 研究重点已由理论概念转向评价指标体系及评价方法 ${ }^{[7]}$, 但目前多数研 究在评价后并未提出具有可行性的管控方案。

生态管控分区是地学分区面向生态领域的发展和应用。国际水环境治理实践表明生态管控分区是当前 水环境管理的趋势之一 ${ }^{[8-9]}$ 。在辨析流域生态敏感性和生态系统服务功能空间分布差异的基础上划定生态 管控分区, 是协调复合生态系统发展与环境保护关系的需要, 为引导流域空间的合理发展提供强有力的支撑。 生态管控分区有助于实现流域生态系统健康这一终极目标, 是我国生态文明建设的重要内容 ${ }^{[10]}$, 符合国家水 污染控制与治理重大专项提出的“分区、分类、分级、分期” 的水环境治理和管理的理念。随着遥感与地理信 息系统等技术的发展,从地理数据结构特征出发的定量、半定量分区方法规避分区的主观判断问题而被广泛 应用 ${ }^{[11-13]}$ 。赵海霞等从水生态健康维护的视角构建水生态敏感性和水生态压力分区指标体系,划定巢湖环 湖空间开发管制分区 ${ }^{[14]}$ 。谢花林等从生态敏感性、生态服务功能重要性辨析空间差异, 划定生态空间 ${ }^{[15]}$ 。 目前, 以湖泊生态系统健康维护为导向的研究正逐步开展, 而针对贵州高原湖泊生态系统健康维护的生态管 控分区却鲜少涉及。

红枫湖属于高原喀斯特深水湖泊, 流域生态系统脆弱, 加之当前贵安新区高强度的城镇化建设与农业开 发活动,其湖泊水环境形势严峻, 相继出现湖泊面积萎缩、边坡硬质化、水质退化、面源污染等生态环境问 题 ${ }^{16]}$ 。红枫湖还是贵阳市重要饮用水源地之一, 湖泊生态系统健康状况及饮用水安全已引起当地管理部门 和学者的高度重视。总结 10 年来红枫湖水污染治理经验表明, 由于夸大受损生态系统的自我修复能力, 重污 染控制、轻生态修复, 全湖无分区对待, 导致其生态治理和修复效果有限 ${ }^{[17]}$ 。因此, 明确以湖泊生态系统维护 为目标生态管控分区, 从全流域的视角关联水陆生态系统, 有助于科学合理的开发湖泊资源、协调湖泊生态系 统结构和功能,对维护湖泊生态系统健康, 实现生态社会的可持续发展具有重要意义。

\section{1 研究区概况}

红枫湖流域位于贵阳市至贵安新区的水陆连通带 及建成区与农耕区交错带 $\left(106^{\circ} 19^{\prime}-106^{\circ} 28^{\prime} \mathrm{E}\right.$ 、 $26^{\circ} 26^{\prime}-26^{\circ} 35^{\prime} \mathrm{N}$ ), 如图 1 所示。流域面积约 1596.0 $\mathrm{km}^{2}$, 近五年, 湖泊面积缩减至 $32.2 \mathrm{~km}^{2}$, 库容降至 4.1 亿 $\mathrm{m}^{3}$ 。流域高原喀斯特地貌特征凸显 ${ }^{[18]}$, 景观破碎, 易受人类活动的干扰和破坏, 生态系统自然恢复速度缓 慢且难度较大。红枫湖主要入湖支流包括羊昌河、麻线 河、后六河、麦翁河。20 世纪 90 年代, 红枫湖由于过度 开发, 曾爆发大面积的蓝、绿藻水华事件, 湖泊生态系统 受损严重 ${ }^{[17]}$ 。为维护湖泊生态系统健康, 扼制水华事 件再次爆发, 贵阳市先后实施两个水污染治理五年规划 （2008一-2012,2013-2017）, 积极推进 “一湖一策” 治 理,使红枫湖水质得到有效提升。

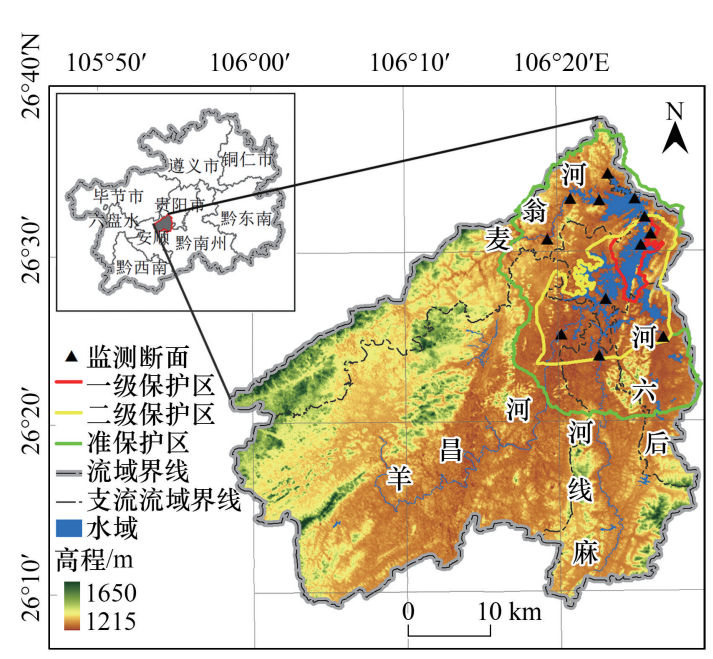

图 1 研究区地理位置

Fig.1 The geographical location of the study area 


\section{2 数据来源与方法}

\section{1 数据来源}

红枫湖湖泊生态系统健康评价指标数据主要来源于野外实地调研、统计数据收集、遥感数据解译。水质、 生物指标数据来自 2017 年逐月开展的 7 个湖区监测点、4 个人湖监测点的实地采样数据。生态敏感性及生 态服务功能评价指标数据主要通过 DEM 数据、气象数据、NPP 数据、土壤数据、遥感影像等计算获取。其中 DEM 数据、2017 年 Landsat8 OLI 遥感影像下载于地理空间数据云 (http://www.gscloud.cn), 气象数据下载于 中国气象数据网 (http://www. data.cma.cn), NPP 数据采用美国蒙大拿大学 (NTSG) 提供的 2000-2017 年 MOD17A3 数据, 中国土壤数据集 (HWSDv1.1)下载于寒区旱区科学数据中心 ( http://data.casnw.net/portal/), 2017 年土地利用类型数据通过 Landsat8 OLI 影像目视解译所得。为更详细的表达空间差异性,提高分区结果 的可靠性, 以 $200 \mathrm{~m} \times 200 \mathrm{~m}$ 的格网为单元进行单要素和多要素的综合评价。

2.2 湖泊生态系统健康评价方法

水利部印发的《湖泊健康评估指标、标准与方法 (试点工作) 1.0 版》 (后简称为《标准》) 是当前较为全面 反映湖泊健康的评价体系, 而被广泛应用, 且实践证明该指标体系能够科学合理的表征我国湖泊生态及功能 特点 ${ }^{[19-20]}$ 。本文参考《标准》提出的湖泊健康评价体系再结合红枫湖的生态状况, 新增换水周期、湖泊补给系 数、重金属潜在风险程度指标共计 16 个指标,涵盖水文水资源、物理结构、水质、生物、社会服务 5 个方面,指 标体系及指标评分结果如表 1 所示, 用于诊断红枫湖湖泊生态系统健康状况。鉴于《标准》里已对各指标的 计算方法及其评价依据、指标权重作详尽的描述, 故严格参照《标准》对各指标进行计算、赋分量化, 根据综合 分值评估湖泊健康状况。湖泊健康分为理想状况、健康、亚健康、不健康、病态 5 个等级, 湖泊健康评估分级标 准如表 2 所示。

\section{表 1 红枫湖湖泊生态系统健康评估指标体系及指标评分结果}

Table 1 Assessment index system and score results of lake ecosystem health in Hongfeng lake

\begin{tabular}{|c|c|c|c|c|c|}
\hline $\begin{array}{l}\text { 目标层 } \\
\text { Target layer }\end{array}$ & & $\begin{array}{l}\text { 准则层 } \\
\text { Criteria layer }\end{array}$ & $\begin{array}{l}\text { 指标层 } \\
\text { Index layer }\end{array}$ & $\begin{array}{l}\text { 评分 } \\
\text { Scores }\end{array}$ & $\begin{array}{l}\text { 数据来源 } \\
\text { Data source }\end{array}$ \\
\hline 湖泊生态系统健康 & 湖泊生态系统 & 水文水资源 $(0.2)$ & 人湖流量变异程度( 0.5$)$ & 90.0 & 水文资料 \\
\hline \multirow{18}{*}{ Lake ecosystem health } & 完整性( 0.7$)$ & & 最低生态水位满足状况 (0.3) & 46.5 & 水文资料 \\
\hline & & & 换水周期( 0.1$)$ & 70.0 & 水文资料 \\
\hline & & & 湖泊补给系数 (0.1) & 80.0 & 水文资料 \\
\hline & & 物理结构 $(0.2)$ & 湖泊萎缩比例 (0.4) & 0.0 & 遥感数据、水文资料 \\
\hline & & & 河湖连通状况 (0.3) & 62.5 & 遥感数据 \\
\hline & & & 湖滨带状况 (0.3) & 63.3 & 遥感数据、统计数据 \\
\hline & & 水质 $(0.2)$ & 富营养状况 & 95.0 & 实地监测 \\
\hline & & & 溶解氧水质状况 ( min) & 98.5 & 实地监测 \\
\hline & & & 耗氧有机物污染状况 & 70.0 & 实地监测 \\
\hline & & & 重金属潜在风险程度 & 60.0 & 文献资料 [21] \\
\hline & & 生物 (0.4) & 浮游植物数量 $(0.15)$ & 76.0 & 统计数据 \\
\hline & & & 浮游动物生物损失指数 (0.15) & 65.0 & 统计数据 \\
\hline & & & 鱼类生物损失指数( 0.2 ) & 70.0 & 统计数据 \\
\hline & & & 大型无脊椎动物生物完整性指数 ( 0.25$)$ & 60.0 & 统计数据 \\
\hline & & & 大型水生植物覆盖度 (0.25) & 80.0 & 遥感数据 \\
\hline & 社会服务 $(0.3)$ & 社会服务功能 & 水功能区达标指标 $(0.4)$ & 83.3 & 实地监测 \\
\hline & & & 水资源开发利用指标 (0.35) & 85.0 & 统计数据 \\
\hline & & & 公众满意度指标( 0.25 ) & 80.0 & 实地调研 \\
\hline
\end{tabular}


表 2 湖泊健康评估分级标准

Table 2 Classification criteria and scoring for health assessment in lake

\begin{tabular}{lccccc}
\hline $\begin{array}{l}\text { 类型 } \\
\text { Type }\end{array}$ & 理想状况 & 健康 & 亚健康 & 不健康 & 病态 \\
Sickness
\end{tabular}

2.3 生态敏感性及生态服务功能评价方法

现阶段以流域为控制单元的生态管控中更多的强调分区内部的生态敏感性及生态服务功能的空间差异， 维护流域生态系统健康的同时,兼顾生态社会的可持续发展。根据《生态保护红线划定指南》 ${ }^{[22]}$ 并结合红枫 湖流域自然生态现状,对生态敏感性及生态服务功能进行评价, 具体评价方法如表 3 所示。根据 2017 年开展 的野外实地调研发现,红枫湖流域农业面源污染现象严峻,应将农业面源污染的关键指标总磷、总氮纳人考 虑。采用土壤保持服务能力指数计算土壤保持功能 ${ }^{[22]}$, 采用生境多样性评价方法评价生物多样性保护功 能 ${ }^{[22]}$,参考赵同谦等的方法评估水源涵养功能 ${ }^{[26-27]}$, 采用生态弹性度指数评价生态恢复功能 ${ }^{[13]}$ 。

表 3 生态敏感性及生态服务功能评价方法

Table 3 Evaluation method of ecological sensitivity and ecological service function

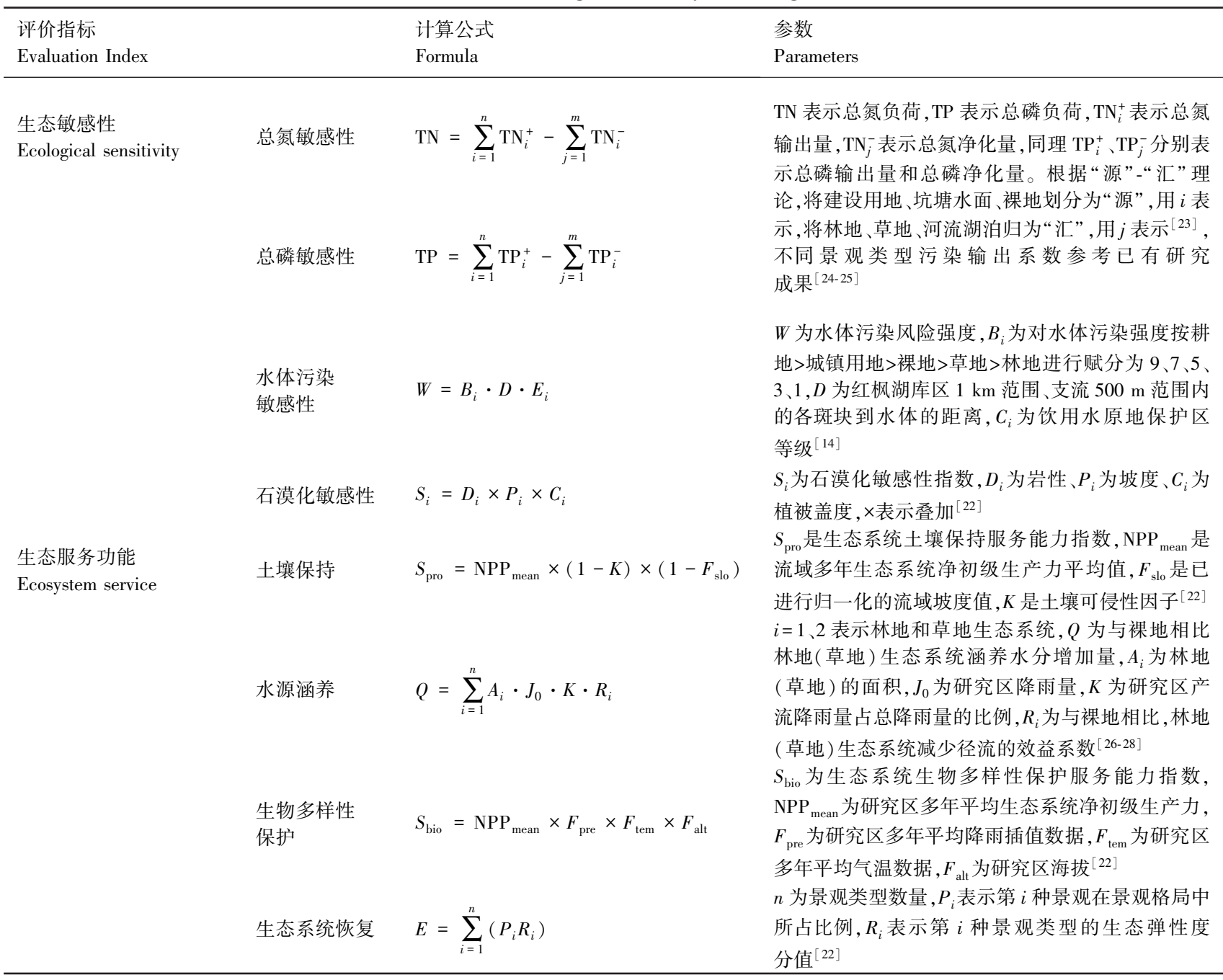

将单指标生态敏感性和单指标生态服务功能评价结果进行标准化,划分为低、较低、中、较高、高 5 个等 级, 采用析取算法得到综合生态敏感性和综合生态服务功能空间分布, 并将其划分为低、较低、中、高 4 个等 级,计算公式如下 ${ }^{[29]}$ : 


$$
\begin{aligned}
& E L_{\text {sen }}=\operatorname{Max}\left(T N, T P, W, S_{i}\right) \\
& E L_{\text {ser }}=\operatorname{Max}\left(S_{\text {pro }}, S_{\text {bio }}, Q, E\right)
\end{aligned}
$$

式中, $E L_{\mathrm{sen}}$ 表示综合生态敏感性用地指数, $E L_{\mathrm{ser}}$ 表示综合生态服务功能用地指数。

2.4 基于 SOFM 神经网络的生态管控分区

由于无法比较单指标生态敏感性和单指标生态服务功能对综合敏感性及综合生态服务功能的贡献比, 因 此不涉及权重差异。为保证分区的客观性、准确性,选用 SOFM 自组织特征映射模型( Self-Organizing Feature Maps,SOFM) 进行空间聚类。SOFM 是一种将高维度数据集映射到低维度并按数据间相似关系进行聚类的网 络模型。SOFM 模型与传统分类方法相比, 能在保持数据拓扑结构不变的前提下进行聚类 ${ }^{[11-12,30]}$ 。本文运用 MATLAB 神经网络工具箱构建 SOFM 网络模型, 将标准化的生态敏感性及生态服务功能指标作为输人层进行 训练, 最大循环次数为 1000 次, 分类类别依次设置为 $3 、 4 、 5$, 依据生态系统空间分异规律、空间连续性、区域 管理可行性优选分区方案,满足区内相似和区际差异要求,确保分区界线清晰和完整。

\section{3 结果与分析}

\section{1 红枫湖湖泊生态系统健康评价}

红枫湖湖泊生态系统健康评价结果如图 2 所示, 各单指标评分如表 1 。经过加权计算, 水文水资源评分 约 73.8 分, 属健康状态, 最低生态水位满足状况堪忧。物理结构评分仅有 37.0 分, 属不健康状态, 现状湖泊面 积与建库初期湖泊面积相比萎缩率高达 $44.0 \%$, 其中降雨径流补给减少、围湖造田、河道淤积是造成湖泊面积 萎缩、河湖联通性较低的重要原因。水质评分约 60.0 分,存在亚健康风险,其饮用水源地水质基本达标, 水体

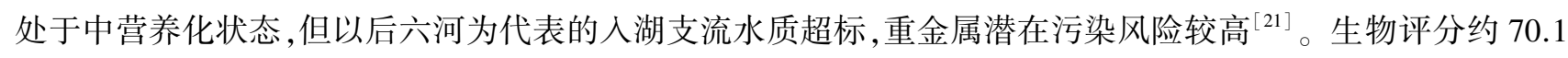
分, 属健康状态, 浮游植物、浮游动物、鱼类、水生植物覆盖度评分较均衡, 仅无脊椎生物完整性评分较低。从 社会服务指标看, 红枫湖评分高于 83.0 分, 水功能区达标率较高, 公众对红枫湖的社会服务基本能达到满意 程度,水资源开发利用强度较大。综合水文水资源、物理结构、水质、生物、社会服务指标得到红枫湖湖泊生态 系统健康评分为 68.4 分, 属于健康状态, 存在亚健康风险, 其中物理结构成为威胁红枫湖湖泊生态系统健康 的主要因子。

\section{2 红枫湖流域生态敏感性评价}

红枫湖流域生态敏感性单指标评价结果如图 3 所示。地表径流输人是湖泊生态系统中总氮的重要来源, 其挟带的陆源氮营养导致湖泊生态系统中氮营养的时空分布差异 ${ }^{[31]}$ 。红枫湖流域总氮敏感性空间分布差异 明显, 高、较高敏感区集中分布于麦翁河及羊昌河上游, 中敏区零星遍布全流域, 较低、低敏区则主要分布于东 南部麻线河和北部饮用水源地周围。

湖泊生态系统是磷元素的主要滞留区域, 磷是水质恶化、湖泊富营养化的关键因子 ${ }^{[31]}$ 。红枫湖流域总磷 敏感性较低,低、较低、中度敏感区面积累积比例达 $80.0 \%$, 低敏区集中于饮用水源地周围,高敏区极少仅占流 域面积的 $3.5 \%$, 分布于羊昌河北部支流。

石漠化地区生态环境脆弱, 地表水资源分布不均, 调蓄能力较弱, 且农药残留物直接渗人地下造成水污 染, 因此, 石漠化敏感性是喀斯特地区开展湖泊生态系统健康维护不容忽视的环境特征。经过多年治理,红枫 湖流域石漠化生态恢复效果较好, 流域以石漠化不敏感区为主, 其次为较低敏感区, 较低敏感区零星分布于麦 翁河、羊昌河、麻线河上游陡坡地区，敏感区分布极少，不足流域面积的 $2.2 \%$ 。

水体污染敏感性反映湖泊水体受外界污染的风险程度,一般认为水体污染敏感性主要与湖滨带土地利用 类型及距离有关 ${ }^{[14]}$ 。水体污染高敏感区分主要分布于红枫湖东南部麻线河中游及下游地区, 低敏感区则主 要位于麦翁河沿岸。

红枫湖流域综合生态敏感性面积占比较均匀 (图 4), 高敏感区集中分布于流域西南部羊昌河流域, 即红 枫湖上游, 该区域广布旱地、水田, 化肥农药施用量较高; 中敏感区除大面积分布于麦翁河流域外,零星散布于 


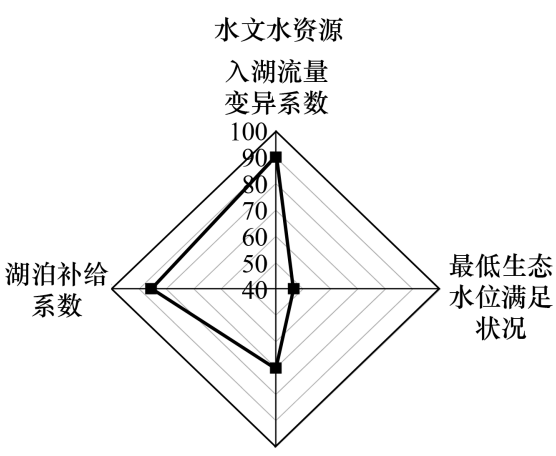

换水周期

水质

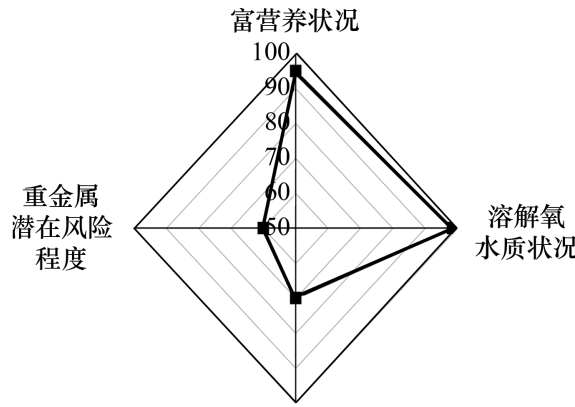

耗养有机物污染状况

社会服务

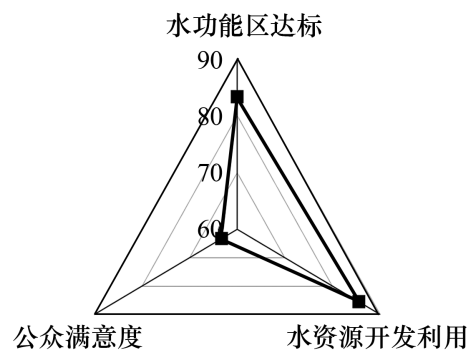

物理结构

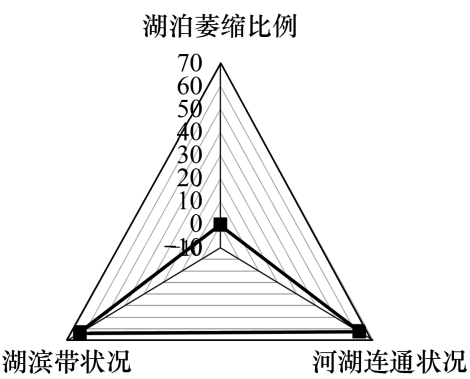

生物

浮游植物数量

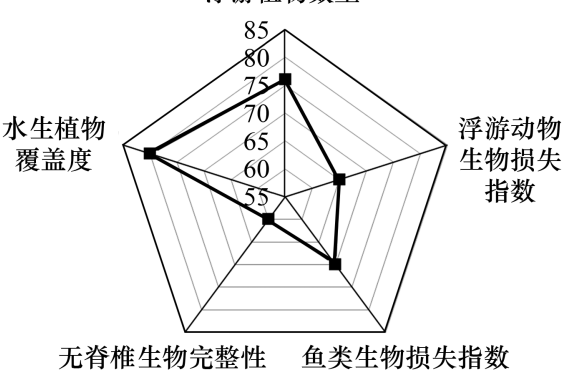

红枫湖湖泊生态系统健康状况 水文水资源

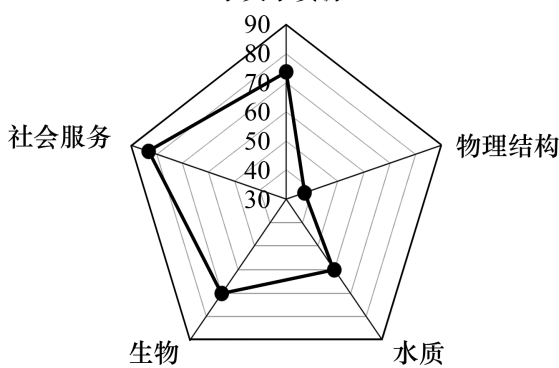

图 2 红枫湖湖泊生态系统健康评价雷达图

Fig.2 Results of ecosystem health assessment of Hongfeng Lake

其他流域;较低敏感区成为中敏感区和低敏感区的过渡带; 低敏感区则主要分布于流域北部饮用水源地周围 及流域东南部麻线河上游。可见, 经过长期水污染治理, 饮用水源地周围植被覆盖度较高, 人类活动对水环境 的负向作用基本遏制,但该区域濒临水体,仍是湖泊生态系统健康维护的关键区域。

\section{3 红枫湖流域生态服务功能评价}

红枫湖流域生态服务功能单指标评价结果如图 5 所示。土壤保持功能与湖泊水环境污染密切相关,土壤 侵蚀不仅增加水体浑浊度,还是面源污染的重要载体。红枫湖流域土壤保持功能空间分布整体呈破碎状, 分 布特征不明显。从面积统计看, 中值区、较高值区分布相当,各占红枫湖流域面积的 $30.3 \%$ 左右。流域地势南 高北低、西高东低, 以森林为主的高植被覆盖区集中于流域南部, 土壤保持功能较高, 而流域北部人类活动频 繁, 土壤保持功能较低。

良好的水源涵养功能是湖泊生态系统水源补给的重要保障。红枫湖流域水源涵养功能表现出明显的空 间异质性和过渡性。流域以低值区为主,连片集中分布于流域西部,占流域面积的 $46.3 \%$, 其次为较低值区， 

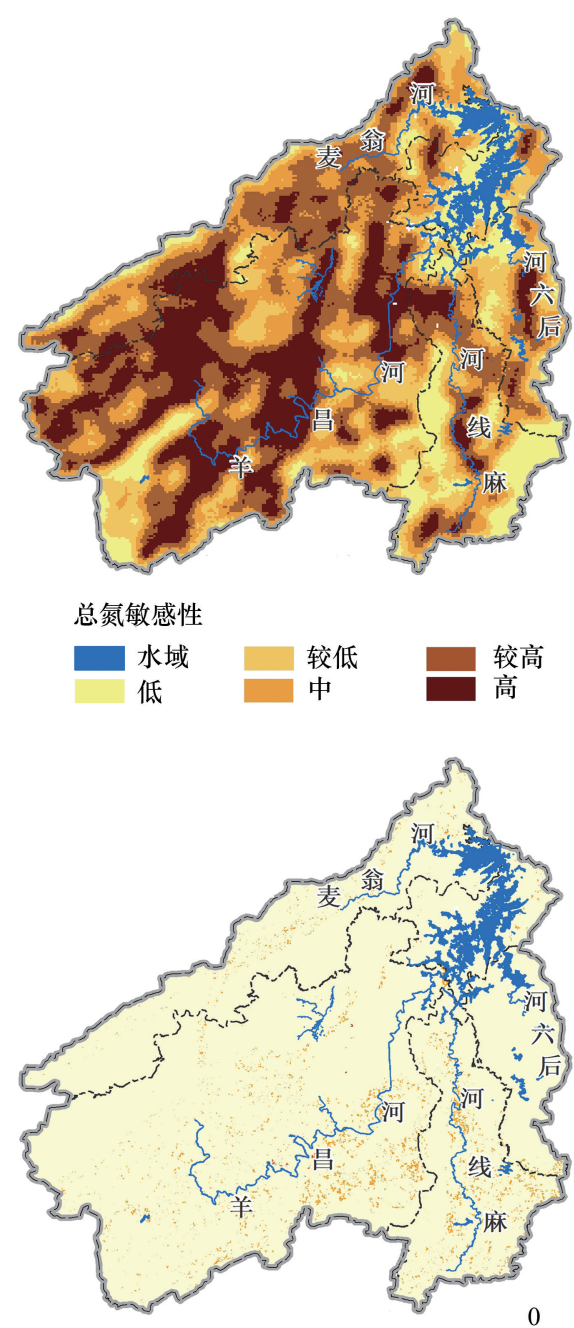

石漠化敏感性

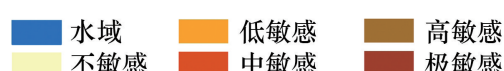

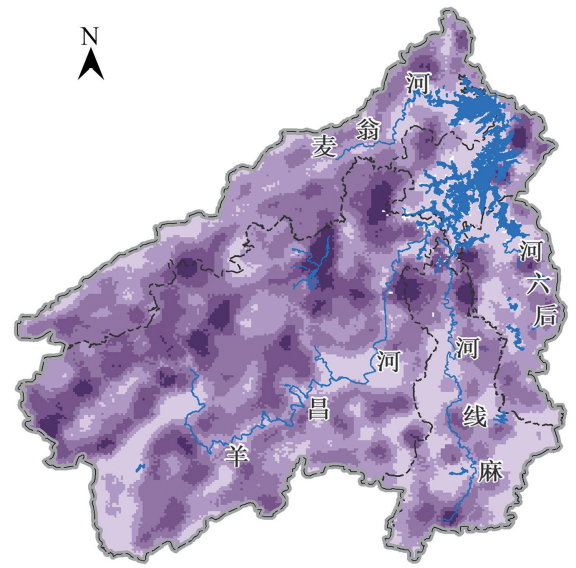

总磷敏感性
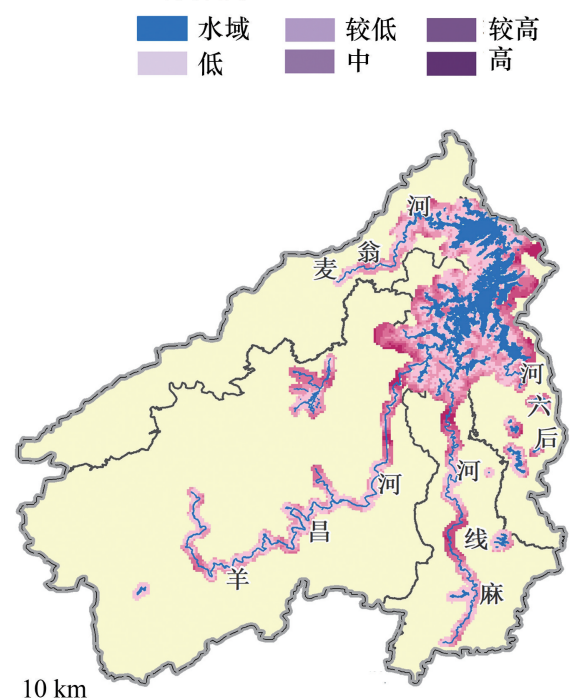

水体污染敏感性

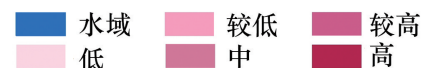

图 3 单指标生态敏感性空间分布图

Fig.3 Spatial distribution of single index of ecological sensitivity

零星遍布全流域。高值区、较高值区集中分布于流域南部羊昌河、麻线河、后六河上游及流域北部湖区人口， 占流域面积的 $14.1 \%$ 。中值区、较高值区、高值区空间分布则呈现出明显的过渡性。

生物多样性变化一定程度上能够反映湖泊生态系统中水文变化程度, 对水资源的调度具有参考意义 ${ }^{[32]}$ 。 生物多样性保护功能空间分布南北差异明显,低值区集中分布于流域北部,高值区、较高值区则集中分布于流 域东南部麻线河上游, 流域西南部羊昌河、麦翁河上游地形起伏度较大地带,较低值区则主要分布于流域中部 准保护区以内,该区域海拔相对较低,地势平坦,为人类活动的集中区域,中值区则散落分布于支流沿岸。

生态系统恢复功能以中值区和较高值区为主,占流域面积的 $66.8 \%$,遍布整个流域,高值区集中于流域北 部湖区周围,零星散落于流域南部,较低值区主要分布于流域中部及西南部。

红枫湖流域综合生态服务功能以低值区为主(图 6), 约占流域面积的 $56.3 \%$,成片分布于流域西南部, 该 区域地势起伏较大, 斑块破碎; 较低值区面积仅占 $5.5 \%$; 中值区及高值区交叉分布于流域东南部,该区域海拔 较高, 林草地密集分布, 受人类活动扰动较小。对比生态敏感性及生态服务功能空间分布可知, 流域西部呈现 出明显的高敏低服务功能特征, 该区域地势相对平缓,农业种植活动及城镇开发活动的扰动,一定程度上限制 
了生态系统服务功能的供给。

\section{4 生态管控分区}

利用 SOFM 神经网络模型对生态敏感性及生态服 务功能共 8 项指标进行空间聚类, 当 SOFM 聚类为 4 类 时,空间自相关 Morans 指数为 $0.59, \mathrm{Z}$ 值远高于 0.01 显 著性水平, 临界值为 2.58 , 表现出明显的全局自相关性, 说明聚类结果满足区内相似和区际差异要求,能够反映 生态空间差异特征。根据流域生态敏感性及生态服务 功能差异、发展和资源利用需求,结合空间聚类结果、野 外实地调研情况和及空间区划原则将红枫湖流域划为 优先控制区、重点控制区、缓冲控制区、一般控制区、如 图 7 所示。

优先控制区占流域面积的 $15.8 \%$, 主要分布于红枫 湖饮用水源地一、二级保护区内, 该区域表现为低生态 敏感性和低生态服务功能, 与 2008-2012 年、20132017 年实施的污水治理专项相关,该区域居民点已搬 离,工业企业已逐步关停或搬离,但历史遗留的重金属 污染仍然严峻。因濒临湖泊水体, 该区域是湖泊生态系

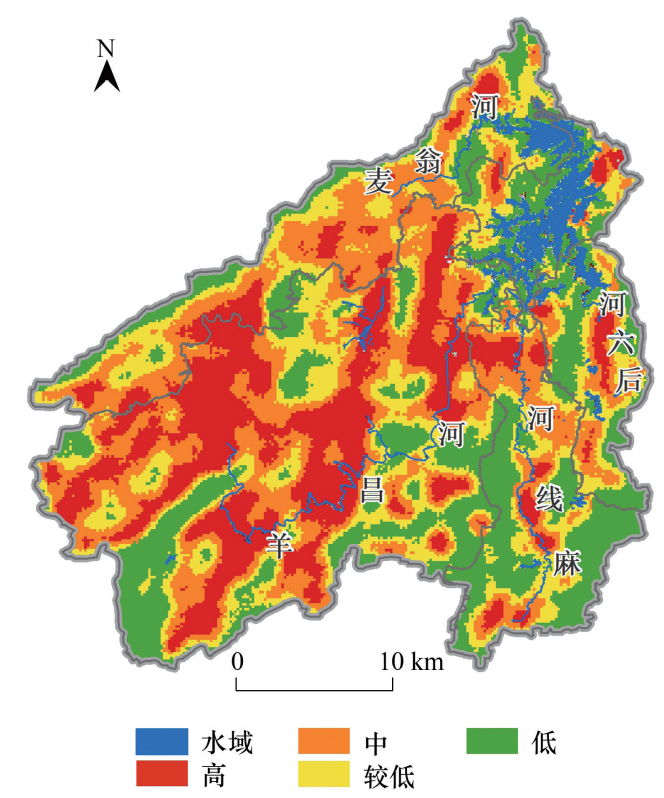

图 4 综合生态敏感性空间分布图

Fig.4 Spatial distribution map of comprehensive ecological sensitivity 统健康维护的关键区域,应实施封闭管理,退田造湖, 控 制周边建设与生产活动对湖泊岸线的侵占,增加环湖监测频次, 保证湖泊水质水量, 加强历史遗留污染治理, 推进生态修复工程, 核查现有截污治污设施, 落实环湖截污管道的闭合运用,进一步完善环湖截污系统。

重点控制区占流域面积的 $6.5 \%$, 集中分布于优先控制区外围及支流沿岸, 是修复和维护湖泊生态系统中 水文水资源和物理结构指标的重点区域。一方面应对底泥淤积厚度较大的支流河段进行清淤,发挥河湖联通 的优势,引水人湖保证水质水量, 缓解湖面萎缩; 另一方面该区域水体污染敏感性较高, 应加强湖滨 (河岸) 带 的维护, 引导种植结构调整, 强化湖滨 (河岸) 带植物、大型水生植物对陆域污染物的阻隔作用, 实施严格的环 境准人条件和污染排放标准, 在提升支流水质的基础上开展生态修复。

缓冲控制区占流域面积的 $26.4 \%$, 主要分布于红枫湖流域上游高海拔地区, 该区域生态敏感性较低而生 态服务功能较高, 水源涵养能力较高、物种丰富、受损后恢复力较强, 受人类扰动较低, 是流域的天然生态安全 屏障,应加强该地区水源涵养林的保护。

一般控制区占流域面积的 $51.3 \%$,遍布流域上游,生态敏感性较高而生态服务功能较低。农业用地是该 区域的主要土地利用类型,粗放型农业生产使该区域总氮和总磷敏感性较高, 人类扰动强烈, 其水源涵养功 能、生态恢复功能较低。一般控制区应加强农业面源污染治理,引导粗放型种植方式向集约型转变,完善各行 政村的污水收集系统, 实现生活污水的源头控制, 积极推进生态修复工程,构筑流域生态安全屏障,推进资源 有序利用和保护性开发。

\section{4 讨论与结论}

\section{1 讨论}

湖泊生态系统健康评价侧重于水域环境, 同时生态敏感性和生态系统服务也是揭示生态系统健康的重要 指标 ${ }^{[33]}$, 更多的侧重于陆域环境。流域是水域、陆域高度关联和互馈的有机整体,高原湖泊流域中水域与陆 域的物质和能量交换强烈, 水域对陆域环境变化响应敏感。红枫湖湖泊生态系统诊断为健康 (评分为 68.4), 属防治结合型湖泊, 发展与保护矛盾突出。生态敏感性及生态服务功能空间差异显著, 表明陆域生态系统结 

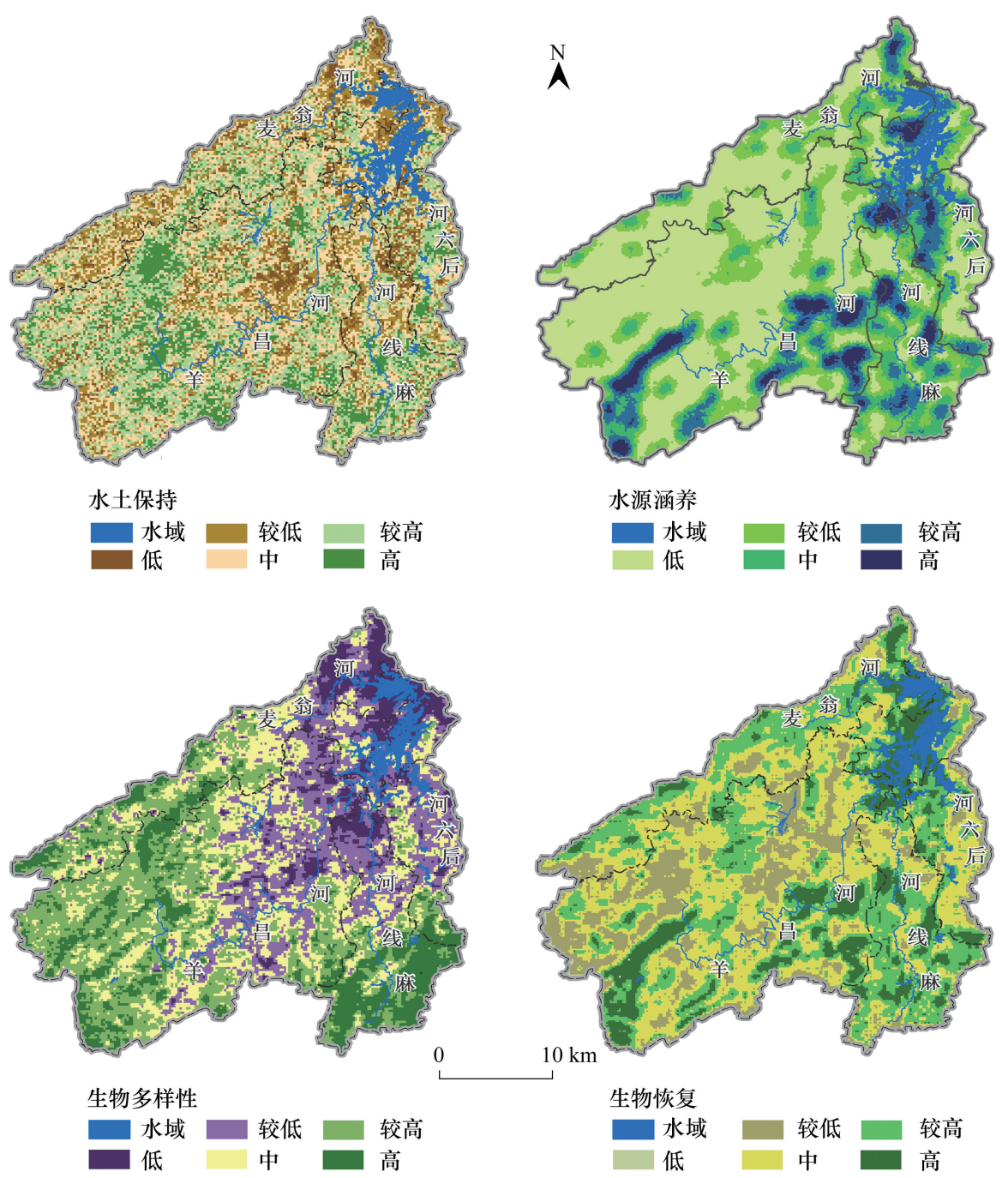

图 5 单指标生态服务功能空间分布图

Fig.5 Spatial distribution of single index of ecological service function

构不合理,生态敏感性较高、高的区域易引发湖泊生态系统的恶化, 而生态服务功能较高、高的区域有助于平 衡水陆物质和能量交换、益于生物多样性保护、具备较强的受损恢复能力。同时,湖泊生态系统健康是流域生 命力的重要体现, 生态服务功能依赖于健康的湖泊生态系统。本研究中, 以湖泊生态系统健康评价结果为导 向,生态敏感性和生态服务功能为基础的生态管控分区的重点任务是调结构、转方式,消除现存及历史遗留污 染源, 逐步修复生态系统。

地学分区思想已被广泛用于水环境管理的各方面,包括水功能分区、水环境功能分区、水生态地理分区、 生态分区等,因其区划依据和目标的不同,各分区优缺点凸显。本文在借鉴已有研究成果的基础上,以生态敏 感性及生态服务功能空间差异进行 SOFM 聚类分区, 其分区结果体现湖泊型流域以湖泊为核心的圈层结构特 征, 由湖泊水体向外依次为优先控制区、重点控制区、缓冲控制区或一般控制区、管控级别遵循优先控制区> 重点控制区>缓冲控制区>一般控制区。空间尺度方面,陆域与湖泊生态系统关联,生态敏感性及生态服务功 能差异是水文水资源、湖滨带结构、湖泊面积、鱼类、大型水生植物、富营养状态、生物量等的重要决定因

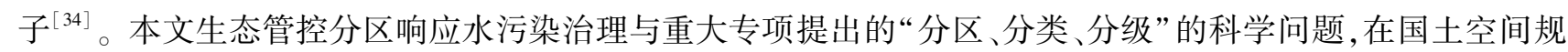
划体系中为上层规划提供科学依据, 是寻求湖泊型流域生态环境可持续发展的空间管控途径探索, 为生态文 明建设提供案例支撑。 


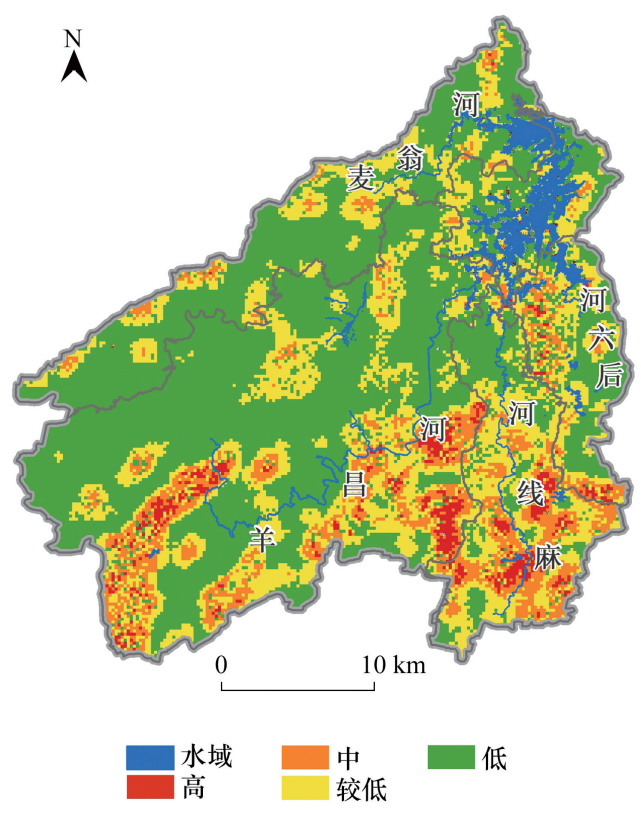

图 6 综合生态服务功能空间分布图

Fig. 6 Spatial distribution of comprehensive ecological services function

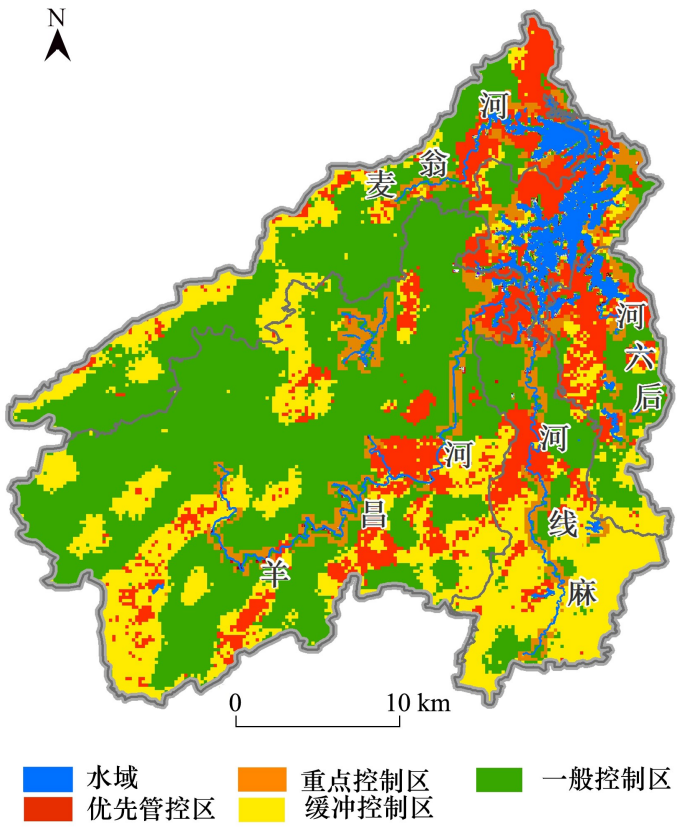

图 7 红枫湖流域生态空间管控区划示意图

Fig.7 Ecological management and control zoning of Hongfeng Lake Basin

本研究是湖泊生态系统健康评价结果的应用初探,参考《标准》改进后的评价体系完整的、系统的识别红 枫湖湖泊生态系统健康问题。然而, 由于长时序监测数据获取困难, 本文仅对红枫湖湖泊生态系统健康现状 作评价, 今后还需完善生态管控分区对湖泊生态系统健康变化的影响。此外,水循环是连接水域、陆域各项生 态过程的纽带, 学界普遍认同流域层面的统筹管理更有利于水环境质量提升,但由于水陆耦合机制研究尚不 成熟, 本文未能充分阐述水陆关联。后续须着重收集基础数据, 通过模型机理识别水域生态系统对陆域生态 系统的响应,依托水陆耦合机理统筹流域综合管理。

\section{2 结论}

(1) 红枫湖生态系统健康评分为 68.4 分, 属健康状态。水文水资源、物理结构、水质、生物、社会服务准则 层中, 物理结构 (评分 37.0 分) 成为威胁湖泊生态系统健康的主导因子, 湖泊萎缩严重, 河湖连通状况较差, 湖 滨带植被盖度较小, 人类活动扰动程度较高; 水质指标中 (评分为 60.0 分), 重金属潜在污染风险较高, 是水质 提升的关键。

(2)红枫湖流域生态敏感性及生态服务功能空间分布差异明显,生态环境脆弱,生态服务功能较低。生 态敏感性高值区主要分布于流域上游,饮用水源地因持续开展水污染治理,生态本底较好,生态敏感性较低。 生态服务功能高值区主要分布于流域南部,羊昌河、麻线河支流沿岸人口密集区域。

(3) 红枫湖流域生态管控分区划为优先控制区、重点控制区、缓冲控制区、一般控制区。面积比例为一般 控制区 $51.3 \%>$ 缓冲控制区 $26.4 \%>$ 优先控制区 $15.8 \%>$ 重点控制区 $6.5 \%$, 管控力度遵循优先控制区>重点控 制区>缓冲控制区>一般控制区。红枫湖流域属防治结合型流域, 发展与保护矛盾突出,生态管控分区的重点 任务是调结构、转方式,逐步修复生态系统。

\section{参考文献 (References) :}

[ 1 ] Bhagowati B, Ahamad K U. A review on lake eutrophication dynamics and recent developments in lake modeling. Ecohydrology \& Hydrobiology, 2019, 19: 155- 166 . 
[ 2 ] Mach M E, Martone R G, Chan K M A. Human impacts and ecosystem services: insufficient research for trade-off evaluation. Ecosystem Services, 2015, 16: 112- 120 .

[ 3 ] Costanza R, Mageau M. What is a healthy ecosystem. Aquatic Ecology, 1999, 33(1): 105-115.

[4] 徐宗学, 顾晓昀, 左德鹏. 从水生态系统健康到河湖健康评价研究. 中国防汛抗旱, 2018, 28(8): 17-24, 29-29.

[ 5 ] Schaeffer D J, Herricks D E, Kerster H W. Ecosystem health: I. measuring ecosystem health. Environmental Management, 1988, 12 (4): 445- 455 .

[ 6 ] Rapport D J, Böhm G, Buckingham D, Cairns Jr J, Costanza R, Karr J R, de Kruijf H A M, Levins R, McMichael A J, Nielsen N O, Whitford W G. Ecosystem health: the concept, the ISEH, and the important tasks ahead. Ecosystem Health, 1999, 5(2): 82-90.

[ 7 ] 孙燕, 周杨明, 张秋文, 易善桢. 生态系统健康: 理论/概念与评价方法. 地球科学进展, 2011, 26(8): 887-896.

[ 8 ] Daniell K A, Barreteau O. Water governance across competing scales: coupling land and water management. Journal of Hydrology, 2014, 519: 2367-2380

[9] 赵思琪, 代嫣然, 王飞华, 梁威. 湖泊生态系统健康综合评价研究进展. 环境科学与技术, 2018, 41(12) : 98-104.

[10］李岁月. 论习近平系列重要讲话的生态空间思想. 内蒙古大学学报: 哲学社会科学版, 2017, 49(5): 15-20.

[11] 毛祺, 彭建, 刘炎序, 武文欢, 赵明月, 王仰麟. 耦合 SOFM 与 SVM 的生态功能分区方法一一以鄂尔多斯市为例. 地理学报, 2019, 74 (3) : 460-474.

[12] 张学儒, 张镱锂, 刘林山, 张继平. 基于 SOFM 神经网络模型的土地类型分区尝试一以青藏高原东部样带为例. 地理研究, 2013 , 32 ( 5 ) : 839-847.

[13] 沙宏杰, 张东, 施顺杰, 刘兴兴. 基于耦合模型和遥感技术的江苏中部海岸带生态系统健康评价. 生态学报, 2018, 38(19): 7102-7112.

[14] 赵海霞, 蒋晓威, 刘燕. 基于水生态健康维护的空间开发管制分区研究一一巢湖环湖地区为例. 生态学报, 2018, 38(3): 866-875.

[15] 谢花林, 姚干, 何亚芬, 张道贝. 基于 GIS 的关键性生态空间辨识——以鄱阳湖生态经济区为例. 生态学报, 2018, 38( 16): 5926-5937.

[16] Wang J F, Chen J G, Ding S M, Guo J Y, Christopher D, Dai Z H, Yang H Q. Effects of seasonal hypoxia on the release of phosphorus from sediments in deep-water ecosystem: a case study in Hongfeng reservoir, southwest China. Environmental Pollution, 2016,219 : 858-865.

[17] 李亦秋, 鲁春霞, 邓欧, 杨广斌. 猫跳河流域梯级开发的生态效应区域响应. 资源科学, 2011, 33(8)：1454-1461.

[18] 许幼霞, 周旭, 赵翠薇, 杨江州, 牛潜. 基于喀斯特脆弱性评价的印江流域生态安全格局构建. 贵州师范大学学报: 自然科学版, 2017, $35(6): 22-29$.

[19］彭文启. 河湖健康评估指标、标准与方法研究. 中国水利水电科学研究院学报, 2018, 16(5): 394-404, 416-416.

[20] 水利部水资源司, 河湖健康评估全国技术工作组. 湖泊健康评估指标、标准与方法. 办资源 [2011] 223 号, 北京: 水利部办公厅, 2011.

[21] 段志斌, 蔡雄飞, 王济, 安吉平. 我国高原型湖泊沉积物重金属污染评价研究. 环境科学与技术, 2017, 40( S1) : 293-298.

[22] 环境保护部, 国家发展改革委. 生态保护红线划定指南. 环办生态 [2017] 48 号, 北京: 环境保护部, 国家发展改革委, 2017.

[23] 欧维新, 连鹏, 逢谦. 基于水污染总量控制的土地利用管控分区一一以无锡市为例. 自然资源学报, 2014, 29(1): 1-12.

[24] 黄国如, 李开明, 曾向辉, 胡海英, 任秀文. 流域非点源污染负荷核算. 北京: 科学出版社, 2014.

[25] Huang J, Xu C C, Ridoutt B G, Wang X C, Ren P A. Nitrogen and phosphorus losses and eutrophication potential associated with fertilizer application to cropland in China. Journal of Cleaner Production, 2017, 159: 171-179.

[26] 赵同谦，欧阳志云，郑华，王效科，苗鸿. 中国森林生态系统服务功能及其价值评价. 自然资源学报，2004，19(4)：480-491.

[27] 赵同谦, 欧阳志云, 贾良清, 郑华. 中国草地生态系统服务功能间接价值评价. 生态学报, 2004,24(6)：1101-1110.

[28］唐玉芝, 郡全琴.乌江上游地区森林生态系统水源涵养功能评估及其空间差异探究. 地球信息科学学报, 2016, 18(7): 987-999.

[29] 熊善高, 秦昌波, 于雷, 路路, 关杨, 万军, 李新. 基于生态系统服务功能和生态敏感性的生态空间划定研究一一南宁市为例. 生态学 报, 2018, 38(22): 7899-7911.

[30] Stankiewicz A, Kosiba P. Advances in ecological modelling of soil properties by self-organizing feature maps of natural environment of lower Silesia (Poland). Acta Societatis Botanicorum Poloniae, 2009, 78(2) : 167-174.

[31] Allan J D, Castillo M M. 河流生态学. 黄钰铃, 纪道斌, 惠二青, 罗玉红, 苏青青, 译. 北京: 中国水利水电出版社, 2017.

[32] 顾西辉, 张强, 孔冬冬, 王月, 刘剑宇. 基于多水文改变指标评价东江流域河流流态变化及其对生物多样性的影响. 生态学报, 2016 , 36 (19) : 6079-6090.

[33] 尤南山, 蒙吉军. 基于生态敏感性和生态系统服务的黑河中游生态功能区划与生态系统管理. 中国沙漠, 2017, 37(1): 186-197.

[34] 高俊峰, 高永年, 张志明. 湖泊型流域水生态功能分区的理论与应用. 地理科学进展, 2019, 38(8): 1159-1170. 